\title{
Evolution of Competition in Vietnam Industries over the Recent Economic Transition
}

\author{
Tinh Doan and Philip Stevens \\ Ministry of Economic Development, Wellington
}

\begin{abstract}
Vietnam has gone through massive economic restructuring from a socialist command economy to market-oriented economy. This provides an excellent example of a country that has experienced changes in competition regime. Economic reforms in late 1980s and 1990s and the introduction of pro-competitive policies in the first half of 2000s have radically altered the economic and, in particular, competitive environment. Understanding the evolution of competition across industries is an important step towards understanding the impact of economic reform on the economic performance of Vietnam as a result of the economic transition. In this paper, the authors investigate the evolution of competition in Vietnam during the economic transition using the price-cost margin (or Lerner Index) and the profit elasticity measure recently developed by Boone (Competition, 2000). This paper provides the first empirical study of intensity and evolution of competition across majority of industries in Vietnam in the last decade using firm-level data from the Vietnam Enterprise Census (VEC) conducted annually since 2000 by the Vietnam General Statistical Office (GSO).
\end{abstract}

JEL D40, L5, L11, P20, P30

Keywords Competition; industry; economic transition; Vietnam.

Correspondence Tinh Doan, Economic Development Policy Branch, Ministry of Economic Development, Wellington, New Zealand; e-mail: thanhtinhdoan@gmail.com

Citation Tinh Doan and Philip Stevens (2012). Evolution of Competition in Vietnam Industries over the Recent Economic Transition. Economics: The Open-Access, Open-Assessment E-Journal, Vol. 6, 2012-19.

http://dx.doi.org/10.5018/economics-ejournal.ja.2012-19.

(c) Author(s) 2012. Licensed under a Creative Commons License - Attribution-NonCommercial 2.0 Germany 
conomics: The Open-Access, Open-Assessment E-Journal

\section{$1 \quad$ Introduction}

In the mid-1980s Vietnam initiated a major economic transition, from a command economy to a market-oriented one. These reforms were extended in the following decades. The introduction of domestic policies such as the first Enterprise law in 2000, Unified Enterprise Law and Competition Law in 2005, in addition to policies to increase international integration, especially WTO accession in 2006, have been designed to unshackle Vietnamese businesses and stimulate competition. These economic shocks are expected to generate a more competitive business environment in Vietnam economy.

These two decades of major economic reform in Vietnam present an excellent opportunity to examine the impact of competition and other economic reform on the level of competitiveness in the economy. However, we currently have little information on the degree of competition and its evolution in the majority of economic sectors in Vietnam during transition to a market economy. To fill this gap, this paper examines the extent and evolution of competition across the majority of industries in the Vietnamese economy. This paper asks the following questions: (a) How competitive are across industries in Vietnam? (b) How has competition evolved during the recent transition? The paper provides evidence on the effects of economic reform and pro-competitive policies on the competition intensity.

This study provides a broad picture of competition across industries in Vietnam rather than detailed analysis of clearly-defined, specific markets that are the provenance of competition agencies. The primary data source for the analysis is the Vietnam Enterprise Census (VEC), a firm-level micro dataset. Firms are classified into sectors according to their major economic activities rather than their products or services. Because of the available data, our primary focus for definitions of 'market' will, therefore, relate to standard industrial definition using the Vietnam Standard Industrial Classification 1993 (VSIC1993).

There are a number of potential candidates for a measure of competition. We briefly discuss a few common measures of these, focussing in particular on a measure-profit elasticity-that has been developed recently to overcome shortcomings of earlier measures. We calculate this profit elasticity measure, in our empirical analysis, along with another popular measure, the price-cost margin, or Lerner index for a range of selected industries in Vietnam. 
The remainder of this paper is structured as follows. In Section 2, we discuss background on economic transition in Vietnam and some key pro-competitive shocks in the last decade. Section 3 briefly reviews the nature and methods for measuring competition. We describe the data in Section 4. In Section 5, we present our results for Vietnam industries. Section 6 concludes and discusses avenues for future research.

\section{Background}

The failure of Soviet-style economic systems in Russia and Eastern European economies in the 1980s stirred the Vietnamese government to implement a series of economic reforms in the mid-1980s and 1990s. These reforms were initially designed to prevent the economy from collapse. They had the effect of freeing-up economic activity, giving households and businesses greater autonomy. Since the reforms of the 1980s and 90s, Vietnam has experienced significant economic growth. Real GDP per capita has increased from US\$98 in 1990 to more than US\$1,000 in 2009 (IMF, 2010). This unprecedented growth represents a major increase in standards of living and has resulted in a considerable reduction in poverty in Vietnam.

The reforms have resulted in a major restructuring of the Vietnamese economy. In the decade since the introduction of the first Enterprise Law in 2000, the number of firms has sextupled, from 40,000 in 2000 to 240,00 2009 (GSO, 2010a; VEC, 2009). ${ }^{1}$ There has also been a significant shift in the nature of economic activity. For example, employment in agriculture, forestry and fishing has declined from 70\% of total employment in 1999 to 52\% in 2009 (GSO, 2010b). This restructuring shows all the signs of Vietnam becoming a dynamic economy-with economic incentives and competitive forces shifting resources to where they are most effectively deployed.

A sharp rise in the number of firms occurred alongside a marked decline in the number of state owned enterprises (SOEs), from about 5,760 in 2000 to 3,200 in 2009 (VEC, 2000 and 2009) over the last decade. This suggests a reduction in direct intervention by the government in economic activities and be good for

\footnotetext{
${ }^{1}$ These exclude micro-firms and household economic units.
} 
competition. However, despite accounting for a relatively small number of firms, SOEs do account for a large proportion of total investment capital-more than $40 \%$ (GSO, 2010a). They also control key industries, and continue to receive privileges from the government, such as using land rent-free and operating in highly profitable industries where private sector competitors are restricted. Therefore, one may argue that the large SOE monopolies would continue to dominate markets, impeding the development of the private sector (e.g. Hersch, Kemme and Bhandari et al., 1994). In addition, whilst the sharp increase in number of firms is dominated by the private sector, this may not be as dynamic and competitive as it fist seems; the number of newly registered firms may be a misleading indicator of private sector expansion (Hakkala and Kokko, 2007) because of dominance or high concentration in industries by small number of SOE big firms. Further, the Communist Party is considered to be politically unwilling to privatize the SOEs. These may imply that the economic transition in Vietnam is still incomplete and so effective competition in Vietnam could potentially still be low.

Nevertheless, Vietnam is an open economy. Foreign trade is very high, with imports and exports being equivalent of 160\% of GDP (Doan and Gibson, 2010), although since the early 1990s, imports have been higher than exports. Import penetration has been observed to create pressure on competition in many other economies, including transition economies (Bugamelli et al., 2010; Chen, Imbs and Scott, 2009; Konings et al., 2005; Raff and Wagner, 2010). As a result of the increasing economic openness and introduction of pro-competitive policies in Vietnam, we expect to observe an increase in the intensity of competition in the economy.

There are a number of factors that may mean the expected increase in the intensity of competition does not eventuate. The policies may have been the inefficiently designed policies. There may have been problems with their implementation. These policies may have been necessary, but not sufficient conditions for a dynamic, competitive economy. It may be the case that remaining regulations and imperfections in the economy prevent the economy from functioning effectively. As we have noted above, the increase in the number of firms during Vietnam's transition may be an insufficient measure of increased competition. For a proper assessment, more robust measures of competition are required. 
conomics: The Open-Access, Open-Assessment E-Journal

\section{$3 \quad$ Competition Definition and Measures}

\subsection{Competition Definition}

Competition is a central concept to economics. At least as far back as the 18th century, with writers such as Adam Smith, economists have been interested in the role of competition in allocating and stimulating economic activity. However, so far there is no a unique definition of competition. Many have tried to revisit the meaning of competition, for instance, Lerner (1934), Stigler (1957), McNulty (1968), and Boone $(2000,2008)$. Although there is no unique definition of competition, firm's market power or extent of monopoly is widely used as an indicator of competition. Monopoly means a firm has market power to profitably raise price over marginal cost, while competition results in decline in supernormal profits of all firms if they have the same marginal costs.

Competition tends to be associated with a decrease in market concentration and profits. However, this property does not always hold; in a fiercer competitive environment, it may be the case that many firms actually increase their market share and profits. Competition is likely to lead to a reallocation effect, where more efficient firms expand their market share at the expense of less efficient ones (Boone, 2000, 2008). Indeed, they can use their cost advantage to force the least efficient firms to exit the market.

\subsection{Competition Measures}

There are essentially three ways in which competition is usually measured: (i) a concentration rate, such as the Herfindahl Index (HI) or a concentration ration; (ii) a measure of rents, such as the price-cost margin (PCM) (also called mark-up or Lerner index); and (iii) more-recently a measure of profit elasticity (PE) (see Domowitz et al., 1986; Blundell et al., 1999; Nickell, 1996; Boone, 2000 and 2008). Amongst these measures, the PCM is the most common empirical measure because of its simplicity and apparent ease of interpretation.

The Lerner Index or Price-Cost Margin is widely used to measure the market power. The difference between firm price $\left(p_{i}\right)$ and marginal cost $\left(c_{i}\right)$ gauges levels of competition in a market. If the difference or margin is nil, that is $p_{i}=c_{i}$, the market is perfectly competitive. When the PCM is greater than zero, firms are able 
to raise prices over their marginal costs. If the margin approaches to one the market is purely monopolistic. Therefore, economists often use PCM to measure competition intensity (Nickel, 1996; Schiersch and Ehmcke, 2010). The PCM for firm $i$ can be written as follows:

$$
P C M_{i}=\frac{p_{i}-c_{i}}{p_{i}}
$$

where $p_{i}$ and $c_{i}$ are the unit price and marginal cost of firm $i$.

To compute the intensity of competition at industry-level, firm's PCM are usually aggregated using market shares, $s_{i}$. The firm' market share $s_{i}$ is used as weight to capture the market power of big firms. The PCM measure of competition in a market or industry $j$ is estimated as follows:

$$
P C M_{j}=\sum_{i \in j}\left(\frac{p_{i}-c_{i}}{p_{i}} \times s_{i}\right)
$$

The problem of implementing PCM measure is that marginal costs and prices in many cases are seldom observed. Thus, in order to calculate PCM we use gross output (sales) and average variable costs instead:

$$
P C M_{j t}=\sum_{i \in j}\left(\frac{p_{i t}-c_{i t}}{p_{i t}} \times s_{i t}\right)=\sum_{i \in j}\left(\frac{y_{i t}-i c_{i t}-w_{i t}}{y_{i t}} \times s_{i t}\right)
$$

where $y_{i t}$ is gross output (sales) of firm $i$ at time $t, i c_{i t}$ is intermediate costs, $w_{i t}$ is labour cost, $s_{i t}$ is the firm's market share in industry $j$ in year $t .^{2}$

The PCM measure has two main drawbacks. First, it is not a robust competition measure (Boone, 2000) because an increase in competition, e.g. the increasing number of firms in a market or an increase in competition among firms in recessions, does not always lead to lower PCM (Amir, 2003; Stiglitz, 1989). Second, PCM measure ignores the reallocation effect. In a fiercer competitive market, more efficient firms may expand their market shares on the cost of less efficient firms. Consequently, the weighted average PCM may increase if the increase in market share $\left(s_{i}\right)$ of more efficient firms is greater than the decrease in

\footnotetext{
${ }^{2}$ For more detail of the variables and their definitions, see Data Appendix.
} 
respective firms' PCM. Thus, PCM measure in this case may be an improper indicator of competition (Boone, 2000; Schiersch and Ehmcke, 2010).

One of the key results emerging from the analysis of large micro databases across the world is the fact that there is a large amount of heterogeneity in firm productivity, even within narrowly-defined industries (Bartelsman and Doms, 2000; Syverson, 2011). The presence of this heterogeneity has an important implication for the measurement of competition.

Consider a market where there is heterogeneity in PCMs due to differences in efficiency. An increase in competition will cause profits to be reallocated from less efficient firms to more efficient firms. Competition adversely affects the profits of less efficient firms harder than those of more efficient firms. Inefficiency is more severely punished in a more competitive market (Boone, 2000 and 2008; Devine et al., 2011). The least efficient firms suffer losses and are forced to exit the market, the exited firms leave behind their market shares and profits for more efficient firms, the survived firms then obtain higher PCMs. The weighted average PCM for an industry may increase or decrease depending on the difference between decrease in individual firm PCM and reallocating output (increase in market shares) to firms with higher PCMs.

This disadvantage of PCM measure motivates Boone (2000) to propose an alternative measure. This has been developed into a new measure of competition called Relative Profits (RP) (Griffith et al., 2005). The spirit of this measure is that competition rewards efficiency. A market maps marginal cost differentials between firms into profit differentials. An increase in competition may lead to the decrease in the market share for less efficient firms but increase for more efficient firms.

Let consider the case where there are two firms in a market with profits defined as $\pi(\eta)$ with the firms having different levels of efficiency $(\eta)$ where $\eta^{\prime \prime}>\eta^{\prime}$. The RP can be calculated as the ratio of the profits of the more efficient firm to the less efficient firm:

$$
R P(\eta)=\frac{\pi\left(\eta^{\prime \prime}\right)}{\pi\left(\eta^{\prime}\right)}
$$

The RP measures the impact of competition via its impact on the relative profits of the two firms. If competition increases, due to more firms entering the 
market for example, leads to higher the RP. This is because as firms respond to the increase in competition will reduce the profits of the more efficient firm by less than less efficient firm. Thus, profits will be reallocated from the less efficient firm $\left(\eta^{\prime}\right)$ to the more efficient firm $\left(\eta^{\prime \prime}\right)$.

Griffith et al. (2005) slightly modified the RP to a more general case for many firms in a market that can be used to measure industry-wide measure of competition, Profit Elasticity (PE). The PE measures the response of profits to changes in costs. When competition increases, inefficient firms take a greater decrease in profits than do more efficient firms. The advantages of this measure are that, under certain assumptions, it is monotonic with competition intensity and requires the same data as the other methods do. The assumptions include firms being completely symmetric except for their efficiency, and firms choose their strategic variables simultaneously and independently (Boone, 2000 and 2008).

Ideally, PE measure is calculated by running an OLS regression of firms' profits $(\pi)$ on their marginal cost. However, the marginal cost is generally not available and so average variable cost $(a v c)$ is used instead (as is the case with measures of PCM):

$$
\ln \left(\pi_{i j}\right)=\alpha+\beta_{j} \ln \left(a v c_{i j}\right)+\varepsilon_{i j}
$$

where profit equals sales $\left(y_{i j}\right)$ of firm $i$ minus total variable cost $\left(t v c_{i j}\right)$; and $a v c_{i j}$ equals to total variable cost $\left(t v c_{i j}\right)$ divided by sales $\left(y_{i j}\right)$. Variable costs are taken to be the sum of labour and intermediate costs.

PE measures how much is change in profits of firms in industry $j$ caused by a unit change in average cost. In other words, the $\beta$ coefficient measures the elasticity of profits with respect to unit change in average cost. The coefficient $\beta$ is expected to be negative, indicating that as firm average cost increases, profits of the firm will decrease. In a more competitive market, $\beta$ will be more negative as profits are more sensitive to changes in average cost. The PE is robust to the competition intensity in presence of the reallocation effect (Boone, 2000 and 2008). This feature is theoretically superior over other competition measures because PE is monotonic with changes in competition intensity, unlike measures such as the PCM or HI.

However, we must be aware that there are a few assumptions underlying the PE measure (Creusen et al., 2006a and 2006b; Schiersch and Schmidt-Ehmcke, 
conomics: The Open-Access, Open-Assessment E-Journal

2010). First, given that the indicator measures competition based on efficiency, it assumes that ranking firms based on their efficiency can be done by ranking them by average costs, which does not seem unreasonable. Second, the PE assumes symmetry in the way that firms respond to changes in competition, given their relative efficiency, 'firm i's profits are the same as firm $j$ 's profits would be if firm $j$ was in firm i's situation' (Athey and Schmutzler, 2001). This is to ensure that the results are due to changes in competition, and not due to changes to the industry structure. Third, as with estimates of PCM, data availability issues leads researchers to calculated the PE using average cost instead of marginal cost. Other problems are unobserved unlevel playing field (that tends to be in favour of the most efficient firm in a certain industry) and the general problem estimates of PE share with other measures of competition of defining the relevant market for firms (Boone, 2000). Boone suggested that comparing competition between industries using PE measure is rather more difficult than identifying changes in the measured competition intensity within an industry over time. This paper focusing on examining evolution of competition during the economic transition matches well this measure. One final issue that affects methods that estimate using natural logarithms is that negative profits or mark-ups will of course remove all negative and zero-profit/mark-up firms from considered sample. Firms clearly cannot sustain negative profits or mark-ups for sustained periods. Nevertheless, this may create a sample selection issue.

\section{$4 \quad$ Data}

The data used in this paper comes from the Vietnam Enterprise Census (VEC). The census has been conducted annually since 2000 by the Vietnam Statistical Office (GSO). The VEC offers a panel dataset from 2000 to 2009. All registered firms ${ }^{3}$ have to fill the questionnaire provided by district statistics offices as legal liability described in the Vietnam Statistical Law. ${ }^{4}$ The VEC provides compre-

3 Although note that some economic activities such as self-employment that economists would consider to be 'firms' may not be included, as we discuss below.

4 GSO has offices in all districts and provinces. The district offices report directly to province statistics offices. 
hendsive information about firms and their activities in the first decade of the twenty first century. The census offers information on firm demographics, ownership, business activities, employment, wages, assets, investment, capital, business performance, revenue, and profit.

Industries or markets have been defined in this paper by the Vietnam Standard Industrial Classification 1993 (VSIC1993) 4-digit industry level codes. This is standard for defining possibly narrowest markets. As with most studies of this type, industries in this paper are defined according to firms' main economic activities. Note, however, that markets can also be defined according to firm products or services.

We removed firms without tax code for some reasons such as missing data or infant firms without tax codes since we use the tax code as firm identifiers to merge data. Some 4-digit industries have very few firms that do not allow us to estimate competition intensity using regressions such as PE, we drop those industries. However, one should bear in mind when considering issues of competition, these industries where there are a small number of players could also be of interest. The focus of this paper is the degree of competition at one-digit level industries, not to study specific markets.

In addition, we exclude some industries that we believe either the current data are not sufficient or the government has not yet treated or allowed them to operate in a market mechanism because of the Communist Party's political doctrine. These industries are 'Agriculture, hunting, forestry and related services', 'Fishing and aquaculture', 'Personal and community services', 'Electricity and water supply', 'Recreational, cultural and sports', 'Healthcare and social work', 'Education and training'. The number of registered firms in the first three industries does not include millions of economic householders who are also producers and competitors such as small farmers, fishermen, café owners, shopkeepers and barbers in the markets. ${ }^{5}$ The current number of registered firms in these industries does not reflect sufficiently number of firms in the playing field and competition intensity. For 'Electricity and water supply', it is simply state monopolistic as few

\footnotetext{
5 There were about 44 million people, out of population of 86 million (GSO, 2010b) in working age in 2009. However, only about 8.3 million working for firms (GSO, 2010a), the remaining of labour force are small economic householders such as farmers, fishermen, other unregistered micro selfemployed households.
} 
conomics: The Open-Access, Open-Assessment E-Journal

state-owned enterprises have been operating in these industries so far. The last three industries have not been fully treated as profit making and financially selfsufficient ones with a market mechanism by the communist government's doctrine and current laws. Therefore, it does not make sense to study competition in these industries.

\section{$5 \quad$ Empirical Results}

In this section we look at the degree of competition in Vietnam industries, both how it compares across broad industries and, in particular, how it has evolved over time.

Before we present our main results it is useful to compare the two measures. As we have noted above, we would not a priori expect the two to be closely correlated, unless the reallocation and selection effects are minimal. Figure 1 confirms this. There is little clear relationship between the PCM and PE measures at 4-digit level The inconsistency between these two measures at 4-digt level suggests that in some industries the reallocation and selection effects are important. Thus, in these cases, fiercer competition had led to reallocation of market shares amongst firms within these industries and for inefficient firms to exit. As this has happened market shares have been reallocated from less-efficient firms to more-efficient firms. In these cases, even where the mark-up of each firm has decreased, the PCM of the overall industry increases. For example, in a study on competition and concentration in New Zealand manufacturing between 1981 and 1991, Ratnayake (1999) found that competition in the industry improved even though market concentration, measured by market share of top 10, top 50 and top 100 enterprises, significantly increased.

The inconsistency between the two competition measures has been well discussed in Creusen et al. (2006a). They argue that higher dispersion in efficiency levels across firms within an industry creates a greater increase in the reallocation effect. An unexpected or ambiguous correlation between the PE and the price-cost margin points to the existence of reallocation effects, i.e. when changes in competition also induce shifts in market shares (Creusen et al., 2006b). These reallocation effects, however, typically emerge if competition is altered by changes 
Figure 1: Scatter Plot PE vs. PCM at 4-Digit Level (2000-2009)

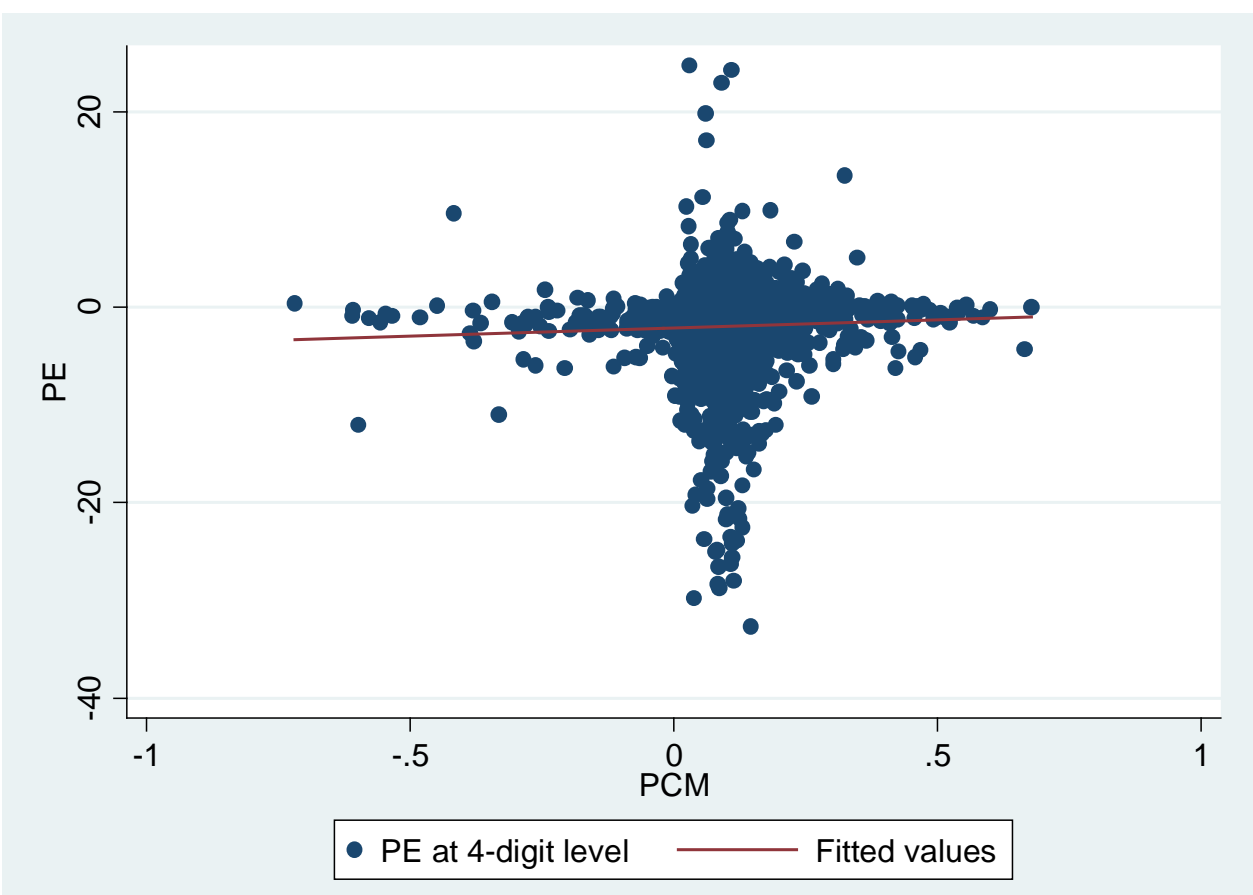

in strategic interaction. PCM measure in this case would incorrectly identify intensity of competition.

Nevertheless, if the underlying shape of the distribution of firm efficiencies within an industry is fairly constant over time, we would expect changes in the two competition measures to me rather more similar.

Figure 2 shows the aggregated one-digit industry PCMs. In the early 2000s, the least competitive sectors were the 'Mining and quarrying', 'Property business, R\&D and consultancy services', 'Transport, storage, travel services, post and telecommunications' and 'Manufacturing' sectors. On the other hand, the markups of the 'Retail trade and individual and household appliance repairs', 'Whole sales', 'Sales and maintenance, repairs of motor vehicles and machinery and related services' and 'Construction' have the are lowest mark-ups and thus the most intense competition. 
conomics: The Open-Access, Open-Assessment E-Journal

Figure 2: Industry Average PCM (2000-2009)

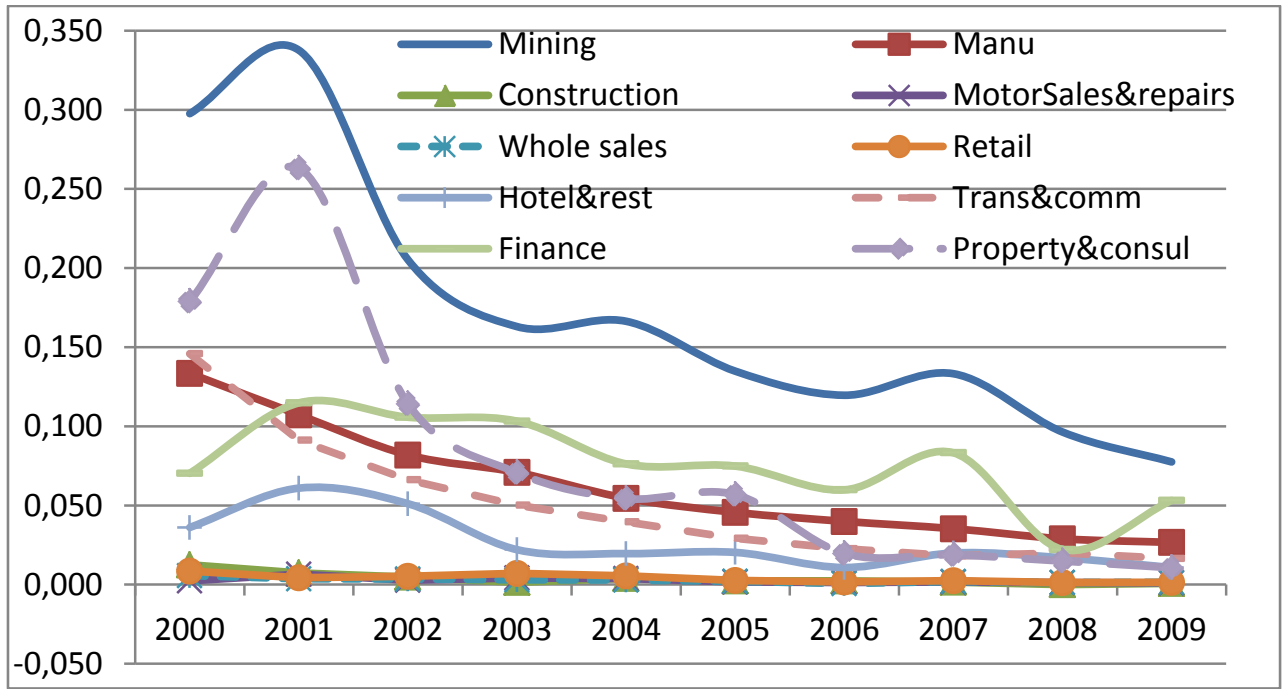

The PCMs declined in all observed industries over the study period, except in period 2000-2001 where the PCM increased in some industries such as 'Mining and quarrying', 'Property business, R\&D and consultancy services', 'Finance' and 'Hotel and restaurants'. This exception would be attributed to effect of introduction of the first Enterprise Law in 2000; a large number of firms were established including the formalization of unregistered small enterprises (Hakkala and Kokko, 2007). The formalization may raise the mark-ups immediately, but effect of the law and massive entry of new firms in subsequent years has led to an increase in competition and lowering PCM. One interesting finding is that competition increased faster over the period in the least competitive industries where the removal of business restrictions played a role. For example, mining, telecommunications, transports, and business consultancy services were considered as politically sensitive industries in Vietnam. These industries were state monopolies and might have had higher PCMs until late 1990s. However, the strict barriers to firm entry in these industries have been gradually removed in 2000s. The PCMs of mining and quarrying, finance (banking) and telecommunications industries are still relatively higher than other industries. This may be due to some entry barriers, such as entry licencing and high start-up capital, which still remained when this paper was written. 
We can consider this trend more formally. We do this by running a regression of the original 4-digit industry competition measures on a time trend or a set of dummies and considering their coefficients. ${ }^{6}$ As Table 1 shows, the trend in PCM is clearly downwards. This is true whether we consider the period one year at a time or include a linear time trend. These results are all statistically significant at the $1 \%$ level.

The PE estimates are presented in Figure 3. These measures are more variable than the PCM measures, but they still show a clear downward trend. This confirms the PCM results that suggest that there has been an improvement in competition

Table 1: Regression of PE and PCM on a Time Trend Variable

\begin{tabular}{|c|c|c|c|c|}
\hline \multirow[b]{2}{*}{ Variable } & \multicolumn{2}{|c|}{ PCM } & \multicolumn{2}{|c|}{$\mathrm{PE}$} \\
\hline & (1) & (2) & (3) & (4) \\
\hline \multirow[t]{2}{*}{ year } & -0.0050 & & -0.1552 & \\
\hline & $(0.0002)^{* *}$ & & $(0.0010)^{* *}$ & \\
\hline \multirow[t]{2}{*}{2001} & & -0.0196 & & -0.3969 \\
\hline & & $(0.0031)^{* *}$ & & $(0.0194)^{* *}$ \\
\hline \multirow[t]{2}{*}{2002} & & -0.0357 & & -0.3368 \\
\hline & & $(0.0030)^{* *}$ & & $(0.0186)^{* *}$ \\
\hline \multirow[t]{2}{*}{2003} & & -0.0443 & & -0.3276 \\
\hline & & $(0.0030)^{* *}$ & & $(0.0182)^{* *}$ \\
\hline \multirow[t]{2}{*}{2004} & & -0.0505 & & -0.3392 \\
\hline & & $(0.0029)^{* *}$ & & $(0.0177)^{* *}$ \\
\hline \multirow[t]{2}{*}{2005} & & -0.0540 & & -0.1419 \\
\hline & & $(0.0028)^{* *}$ & & $(0.0173)^{* *}$ \\
\hline \multirow[t]{2}{*}{2006} & & -0.0598 & & -0.7433 \\
\hline & & $(0.0028)^{* *}$ & & $(0.0170)^{* *}$ \\
\hline \multirow[t]{2}{*}{2007} & & -0.0603 & & -1.0470 \\
\hline & & $(0.0027)^{* *}$ & & $(0.0168)^{* *}$ \\
\hline \multirow[t]{2}{*}{2008} & & -0.0634 & & -1.0494 \\
\hline & & $(0.0027)^{* *}$ & & $(0.0165)^{* *}$ \\
\hline \multirow[t]{2}{*}{2009} & & -0.0646 & & -1.3756 \\
\hline & & $(0.0027)^{* *}$ & & $(0.0164)^{* *}$ \\
\hline \multirow[t]{2}{*}{ Const } & 10.1151 & 0.1929 & 310.5280 & -0.0392 \\
\hline & $(0.3098)^{* *}$ & $(0.0044)^{* *}$ & $(1.9158) * *$ & $(0.0269)$ \\
\hline
\end{tabular}

Note: Significant at $1 \%(* *)$, at $5 \%(*)$; in columns (2), (4) year 2000 is set as base year. PCM and $\mathrm{PE}$ are measured at 4-digit industry level. All models are controlled for one-digit industry fixed effect.

${ }^{6}$ We also include a set of 1-digit industry dummies. 
level of all considered industries in Vietnam. The PE results suggest that either the impact of the reforms was lower in the early part of the period and picked up considerably at the end.

Figure 3 also suggests that introductions of the first Enterprise Law in 2000, the Unified Enterprise Law and Competition Law in 2005 had pro-competitive effects. In both years 2000 and 2005 the competition became fiercer. All the curves except finance sector became steeper after 2005. Additionally, effect of the economic downturn started in 2008 would be the potential underlying reason for a sharp decline (more negative) in PE in a period 2008-2009.

The substantial increase in competition in finance sector prior to 2004 can be explained by massive entry of many new commercial banks, insurance and investment funds and by the looser monetary policy, especially interest rate cuts over period 2001-2005, which aimed to stimulate economic growth after the financial crisis and economic downturn in the period of 1998-2001 in Vietnam. In contrast, the tighter monetary policy to fight inflation and harder regulations on establishing new banks (e.g. the rise in the level of capital required by law since 2005) could explain the degraded level of competition in this industry after 2005. It is worth noting that whenever the State Bank of Vietnam raises the base interest

Figure 3: Industry Average PE (2000-2009)

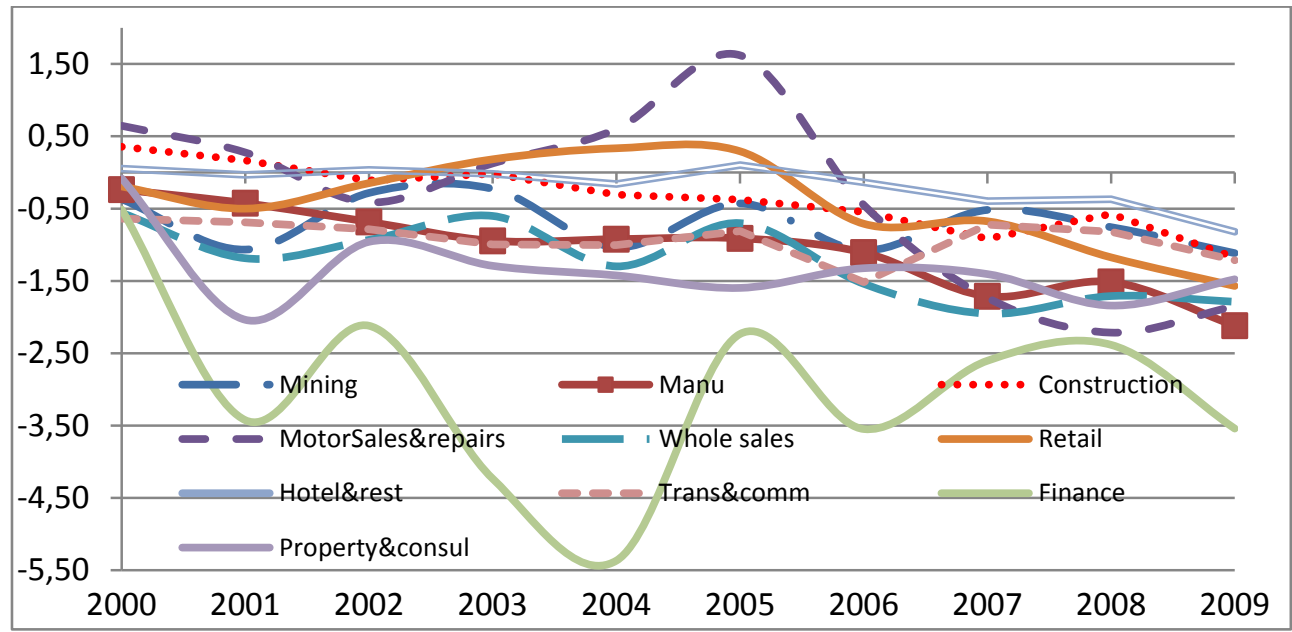


rate, ${ }^{7}$ commercial banks are able to lend at maximum $150 \%$ of the base rate, their competition is then restrained by this regulation. On the other hand, banks are able to be more flexible to compete with others by lowering lending rates when there is no pressure on the capital market.

These results also hold when we regress the four digit industry PE measures on a time trend (or year dummies). Again the coefficients are statistically significant at the $1 \%$ level. The final column (Table 1 ) confirms the higher degree of variability in the estimate for PE than that for the PCM. Nevertheless, the overall result is still the same: a downward trend in the measure, suggesting increasing competition over the period.

The flatter period of competition intensity measured in the final column of Table 2 occurred in a period where the Vietnamese government implemented many policies to stimulate economic growth after four years of economic recession (1998-2001) and deepened reforms to prepare for WTO accession in late 2006. The period 2001-2005 is often called 'integration' period and targeting a TWO membership for Vietnam (Pham, 2006). It may have been the case that during this period there were rather more negative or zero-profit firms. We consider this sample selection issue in more detail below.

Figures 2 and 3, and Tables 1 and 2 will disguise the heterogeneity of experiences of the individual industries over the period. Whilst the overall trend is clearly of an increase in competition, is this change ubiquitous? For this reason, we now look at changes in competition intensity at the component industry level to provide more robust analysis on the improved level of competition.

Figure 4 shows that competition has improved across the majority of 4-digit industries in Vietnam over 2000-2009. ${ }^{8}$ PE measure suggests that there is a larger group, with about two thirds of industries appearing to have an improvement in competition. $^{9}$

\footnotetext{
${ }^{7}$ When there is inflation and capital demand pressure.

8 Similar results hold for the PCM.

9 To reduce missing values for some 4-digit industries, we estimate means of PE for two periods 2000-2001 and 2008-2009 then take the deviation. Some industries those have no data on either of the two periods are removed.
} 
Figure 4: Change in PE by 4-digit level industry over 2000-2009

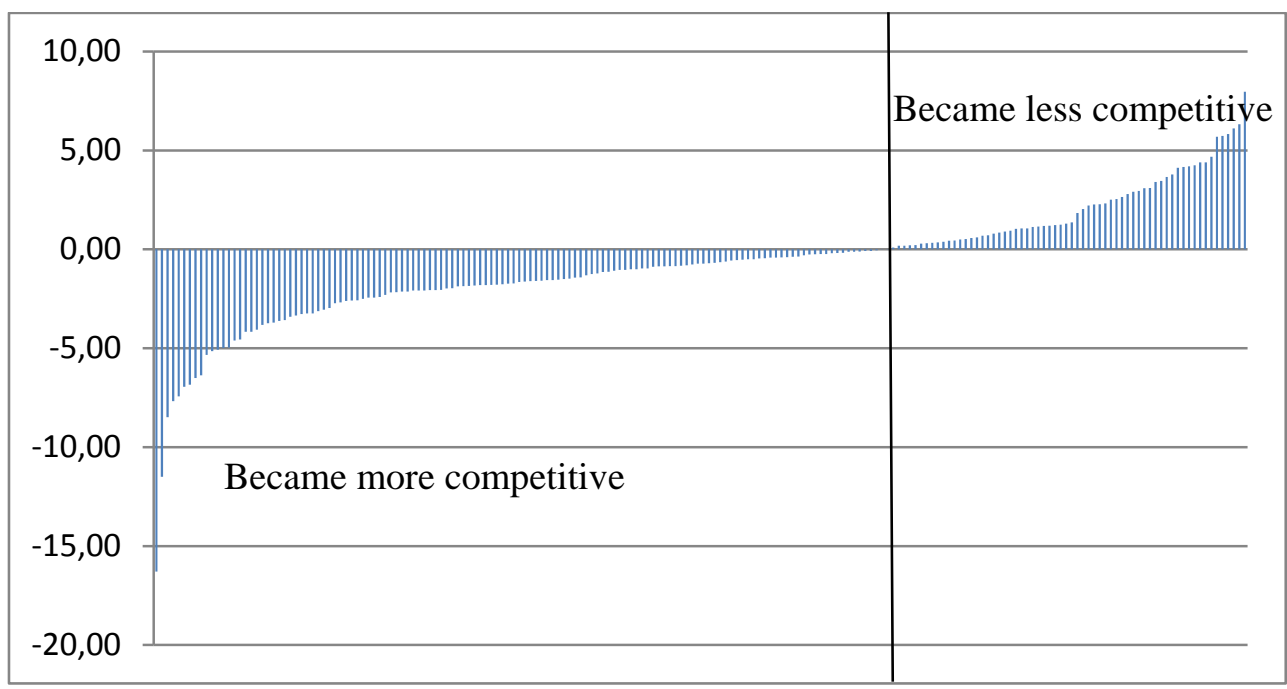

The measure of competition at 4-digit level industries roughly shows a consistent story about improved competition, although some 4-digit industries became less competitive. The increasing trend of competition accords well with other studies on transition economies where pro-competitive policies or shocks such as economic restructuring, privatization, increase in number of firms, and economic openness are believed to be associated with improvement in competition (Carlin, Fries, Schaffer and Seabright, 2001; Hersch et al., 1994; Vagliasindi, 2001).

The greatest absolute improvement is observed in 'Finance', 'Sales and maintenance, repairs of motor vehicles and machinery and related services', and in 'Manufacturing. But the higher relative rise is observed in 'Property business, R\&D and consultancy services', 'Hotel and restaurants', and 'Manufacturing industries. In contrast, the least improvement both absolute and relative are found in 'Mining and quarrying' and 'Transport, storage, travel services, post and telecommunications', though competition in these industries has steadily risen over the period.

In 2009, industries such as mining \& quarrying, construction, hotels and restaurants, and transport, storage and communications appear to be less 
conomics: The Open-Access, Open-Assessment E-Journal

responsive to cost changes than other industries such as finance, manufacturing and whole sales.

\section{Sensitivity Analysis}

The PE is measured by econometric means. In some of the cases the coefficient on average costs is imprecisely estimated. In order to test whether these imprecisely estimated PE scores are driving our results, we re-run the regressions in Table 1 for the subset of firms for whom we have a statistically significant PE. Whilst the coefficients change, the pattern is still clear: competition appears to increasing over the period of our analysis (Table 2).

\section{Concluding Remarks}

This paper has considered the measurement of competition intensity in Vietnam and its evolution over the first decade of the twenty first century. During this period a number of important pro-competitive policies were introduced in Vietnam. We have employed two measures of competition-the Price-Cost Margin and Profit Elasticity. The latter is claimed in the literature to be robust to the reallocation effect that afflicts more conventional measures used in the empirical analysis of competition. We have calculated these two measures for a range of selected industries in Vietnam using ten Vietnam Enterprise Censuses initiated since 2000 by the General Statistical Office.

The measures of competition examined in this paper show that competition in Vietnam has increased significantly between 2000 and 2009. Competition appears to have improved particularly after introduction of the Unified Enterprise Law and Competition Law in 2005. The improvement in competition could be attributed to the massive rise in number of firms. In 2000 there were approximately 42,000 firms in Vietnam. This had increased to more than 240,000 firms by 2009. ${ }^{10}$ Another potential explanation has been the exposure to external competition since Vietnam deepened economic integration in the 2000s (particularly accession to WTO in 2006). Further, the economic recession in late 2000s may also have created more competitive pressure on firms.

10 These number does not include micro-firms and household economic units 
conomics: The Open-Access, Open-Assessment E-Journal

Table 2: Regression of PE and PCM for Subsample with Significant PE

\begin{tabular}{|c|c|c|c|c|}
\hline & \multicolumn{2}{|c|}{$\overline{P C M}$} & \multicolumn{2}{|c|}{$\mathrm{PE}$} \\
\hline Variable & (1) & (2) & (3) & (4) \\
\hline \multirow[t]{2}{*}{ year } & -0.0061 & & -0.1570 & \\
\hline & $(0.000)^{* *}$ & & $(0.0011)^{* *}$ & \\
\hline \multirow[t]{2}{*}{2001} & & -0.050 & & -0.6935 \\
\hline & & $(0.005)^{* *}$ & & $(0.0291)^{* *}$ \\
\hline \multirow[t]{2}{*}{2002} & & -0.083 & & -0.3903 \\
\hline & & $(0.005)^{* *}$ & & $(0.0268)^{* *}$ \\
\hline \multirow[t]{2}{*}{2003} & & -0.086 & & -0.2515 \\
\hline & & $(0.005)^{* *}$ & & $(0.0267)^{* *}$ \\
\hline \multirow[t]{2}{*}{2004} & & -0.110 & & -0.1957 \\
\hline & & $(0.005)^{* *}$ & & $(0.0250)^{* *}$ \\
\hline \multirow[t]{2}{*}{2005} & & -0.107 & & 0.0357 \\
\hline & & $(0.005)^{* *}$ & & (0.0248) \\
\hline \multirow[t]{2}{*}{2006} & & -0.116 & & -0.8151 \\
\hline & & $(0.004)^{* *}$ & & $(0.0247)^{* *}$ \\
\hline \multirow[t]{2}{*}{2007} & & -0.112 & & -1.1934 \\
\hline & & $(0.004)^{* *}$ & & $(0.0243)^{* *}$ \\
\hline \multirow[t]{2}{*}{2008} & & -0.119 & & -0.9434 \\
\hline & & $(0.004)^{* *}$ & & $(0.0241)^{* *}$ \\
\hline \multirow[t]{2}{*}{2009} & & -0.120 & & -1.2373 \\
\hline & & $(0.004)^{* *}$ & & $(0.0240)^{* *}$ \\
\hline \multirow[t]{2}{*}{ Const } & 12.306 & 0.269 & 313.95 & -0.2435 \\
\hline & $(0.403)^{* *}$ & $(0.006)^{* *}$ & $(2.2326)^{* *}$ & $(0.0343)^{* *}$ \\
\hline
\end{tabular}

Note: Significant at $1 \%\left({ }^{* *}\right)$, at $5 \%\left({ }^{*}\right)$; in columns (2), (4), (2b) and (4b) year 2000 is set as base year. PCM and PE are measured at 4-digit industry level. All models are controlled for one-digit industry fixed effect.

Whilst it is intuitive that the increase in number of firms and economic integration or import penetration can be potential factors affecting competitive evolution, a plethora of other factors, such as privatisation, pro-competitive policies, market entry barriers, import penetration, R\&D, advertisement intensity, FDI may also have roles to play. Future work in this area should look at 
conomics: The Open-Access, Open-Assessment E-Journal

determinants of competition to see drives of competition improvement during the economic transition.

Acknowledgement The opinions, findings, recommendations and conclusions expressed in this paper are those of the authors. The work as the authors' own research is done after hours, and hence the Ministry of Economic Development, New Zealand takes no responsibility for content, any omissions or errors in the information contained in this paper. Access to the data used in this study complied with security and confidentiality provisions of the Vietnam Statistics Law 2003. Only people authorized by the Vietnam Statistics Law 2003 are allowed to see data about a particular individual, household, business or organization. The results in this paper have been confidentialised to protect individual businesses from identification.

\section{Appendix: Data and Variables}

Key variables used in this paper are defined as below.

Sales of goods and services (GO) include total sales of products and services, and other incomes excluding fixed asset sales. Profits are total before-tax profits. Employment comes from counts of employees and working proprietors, an average of year-begin and year-end counts. A working proprietor is assumed to be a person who (i) operates his or her own enterprise or engages independently in a profession or trade, and (ii) receives income from self-employment from which tax is deducted, but not from wages and salary.

Fixed assets are averaged over beginning and ending year fixed assets. Variable costs include intermediate costs (IC) and labour costs. Labour cost includes wages, allowance, contribution to social and health insurance, and union fees paid by firms for employees. The intermediate costs include materials, tools, fuel, electricity, water bills, transport expenses, postage, and insurance. Because IC is not explicitly collected in the census, the IC is estimated as the difference between total sales minus sum of labour cost, capital cost (or capital services) and before-tax profits. Capital services cost is estimated as follows:

Capital cost $=$ Depreciation + interest rate*fixed assets

Where depreciation is the difference between year-end and year-begin accumulated depreciation. The difference is actually the depreciation incurs during 
the business year. Some observations with negative depreciation that may be due to selling fixed assets (the difference is negative) were dropped. Interest rate is yearly average interest rate, equals $150 \%$ of the base rate of the State Bank of Vietnam (Central Bank). The State Bank of Vietnam periodly sets the base rate for commercial banks, commercial banks are allowed to lend at maximum $150 \%$ of the base rate. In reality, the commercial banks always lent businesses at $150 \%$ of the base rate as the demand for capital in the economy exceeded the capital supply at the $150 \%$ of the base rate.

Some observations without profit data are dropped. Addionally, PE estimation uses natural logarithm of profit data on the left hand side of the model so that observations with negative or zero profit data are dropped. As a result, the PE estimates are biased and not compatible with PCM because least efficient firms are eliminated from the sample. 
conomics: The Open-Access, Open-Assessment E-Journal

\section{References}

Amir, R. (2003). Market structure, scale economies and industry performance. CORE Discussion Paper No. 2003065, Center for Operations Research and Econometrics (CORE), Université catholique de Louvain. http://ideas.repec.org/p/cor/louvco/2003065.html

Athey, S., and Schmutzler, A. (2001). Investment and market dominance. RAND Journal of Economics 32(1): 1-26. http://papers.ssrn.com/sol3/papers.cfm?abstract_id=252295

Bartelsman, E.J., and Doms, M. (2000). Understanding productivity: lessons from longitudinal microdata. Journal of Economic Literature 38(3): 569-594. http://ideas.repec.org/a/aea/jeclit/v38y2000i3p569-594.html

Blundell, R., Griffith, J., and van Reenen (1999). Market share, market value and innovation in a panel of British manufacturing firms. Review of Economic Studies 66(3): 529-554. http://ideas.repec.org/a/bla/restud/v66y1999i3p52954.html

Boone, J. (2000). Competition. CEPR Working Paper No. 2636. Centre for Economic Policy Research, London. http://ideas.repec.org/p/cpr/ceprdp/2636.html

Boone, J. (2008). A new way to measure competition. The Economic Journal 118(531): 1245-1261. http://ideas.repec.org/a/ecj/econjl/v118y2008i531p1245-1261.html

Bugamelli, M., Fabiani, S., and Sette, E. (2010). The pro-competitive effect of imports from China: An analysis on firm-level price data. Economic Working Paper 737, Economic Research and International Relations Area, Bank of Italy, Rome. http://ideas.repec.org/p/bdi/wptemi/td_737_10.html

Carlin, W., Fries, S., Schaffer, M., and Seabright, P. (2001). Competition and enterprise performance in transition economies: Evidence from a crosscountry survey. William Davidson Institute Working Paper No. 376, William Davidson Institute at the University of Michigan. http://ideas.repec.org/p/wdi/papers/2001-376.html

Chen, N., Imbs, J., and Scott, A. (2009). The dynamics of trade and competition. Journal of International Economics 77(1): 50-62. http://ideas.repec.org/a/eee/inecon/v77y2009i1p50-62.html 
Creusen, H., Minne, B., and van der Wiel, H. (2006a). Measuring competition in the Netherlands. CPB Memorandum No. 163, CPB Netherlands Bureau for Economic Policy Analysis. http://ideas.repec.org/p/cpb/memodm/163.html

Creusen, H., Minne, B., and van der Wiel, H. (2006b). Competition in the Netherlands: An analysis of the period 1993-2001. CPB Document 136, Netherlands Bureau for Economic Policy Analysis.

http://www.cpb.nl/en/publication/competition-netherlands-analysis-period1993-2001

Devine, H., Doan, T., Iyer, K., Mok. P., and Stevens, P. (2011). Competition in New Zealand industries: Measurement and evidence. Paper presented at the 2011 NZAE Annual Conference, Wellington.

Doan, T. and Gibson, J. (2010). Return to schooling in Vietnam during economic transition: Does the return reach its peak? MPRA Working Paper 24984, University Library of Munich, Germany. http://ideas.repec.org/p/pra/mprapa/24984.html

Domowitz, I., Hubbard, G., and Petersen, B. (1986). Business cycles and the relationship between concentration and price-cost margins. RAND Journal of Economics 17(1): 1-17.

http://ideas.repec.org/a/rje/randje/v17y1986ispringp1-17.html

Griffith, R., Boone, J., and Harrison, R. (2005). Measuring competition. AIM Research Paper No. 22, Advanced Institute of Management Research, London. http://papers.ssrn.com/sol3/papers.cfm?abstract_id=1307004

GSO (2010a). The enterprises in Vietnam 9 years at the beginning of century 21. Statistical Publishing House, General Statistics Office. Hanoi, Vietnam.

GSO (2010b). Population and housing census, 1 April 2009 (Complete report and major findings, General Statistical Office). Hanoi, Vietnam. http://www.gso.gov.vn/default_en.aspx?tabid=515\&idmid=5\&ItemID=9813

Hakkala, K., and Kokko, A. (2007). The state and the private sector in Vietnam. EIJS Working Paper No. 236, The European Institute of Japanese Studies, Stockholm, Sweden. http://ideas.repec.org/p/hhs/eijswp/0236.html

Hersch, P., Kemme, D., and Bhandari, S. (1994). Competition in transition economies: determinants of price-cost margins in private sector manufacturing in Eastern Europe. Southern Economic Journal 61(2): 356-366. 
conomics: The Open-Access, Open-Assessment E-Journal

IMF (2010). World economic outlook database. International Monetary Fund, Washington, D.C.

http://www.imf.org/external/pubs/ft/weo/2010/01/weodata/weoselser.aspx?a= $\& \mathrm{c}=582 \& \mathrm{t}=1$

Konings, J., Cayseele, P., and Warzynski, F. (2005). The effects of privatization and international competitive pressure on firms' price-cost margins: Micro evidence from emerging economies. Review of Economics and Statistics 87(1): 124-134. http://ideas.repec.org/a/tpr/restat/v87y2005i1p124-134.html

Lerner, A. (1934). The concept of monopoly and the measurement of monopoly power. Review of Economic Studies 1(3): 157-175.

http://restud.oxfordjournals.org/content/1/3/157.extract

McNulty, P. (1968). Economic theory and the meaning of competition. The Quarterly Journal of Economics 82(4): 639-656.

Nickell, S. (1996). Competition and corporate performance. Journal of Political Economy 104(4): 724-746.

http://ideas.repec.org/a/ucp/jpolec/v104y1996i4p724-46.html

Pham, A. (2006). Economic growth and balance of payments constraint in Vietnam. Vietnam Economic Management Review 1: 51-65.

http://vjol.info/index.php/VEMR/article/viewArticle/580

Raff, H., and Wagner, J. (2010). Intra-industry adjustment to import competition: Theory and application to the German clothing industry. The World Economy 33(8): 1006-1022.

http://ideas.repec.org/a/bla/worlde/v33y2010i8p1006-1022.html

Ratnayake, R. (1999). Industry concentration and competition: New Zealand experience. International Journal of Industrial Organization 17(7): 10411057. http://ideas.repec.org/a/eee/indorg/v17y1999i7p1041-1057.html

Rosenthal, R. (1980). A model in which an increase in the number of sellers leads to a higher price. Econometrica 48(6): 1575-1579.

http://ideas.repec.org/a/ecm/emetrp/v48y1980i6p1575-79.html

Schiersch, A., and Schmidt-Ehmcke, J. (2010). Empiricism meets theory: Is the Boone-indicator applicable? Discussion Papers of DIW Berlin No. 1030, DIW Berlin, German Institute for Economic Research.

http://ideas.repec.org/p/diw/diwwpp/dp1030.html 
Stigler, G. (1957). Perfect competition, historically contemplated. Journal of Political Economy 65: 1-17.

http://ideas.repec.org/a/ucp/jpolec/v65y1957p1.html

Stiglitz, J. (1989). Imperfect information in the product market. In Schmalensee, R., and Willig, R. (eds), Handbook of Industrial Organization Vol. I. Amsterdam, Netherlands. http://ideas.repec.org/h/eee/indchp/1-13.html

Syverson, C. (2011). What determines productivity? Journal of Economic Literature 49(2): 326-65. http://ideas.repec.org/a/aea/jeclit/v49y2011i2p32665.html

Vagliasindi, M. (2001). Competition across transition economies: an enterpriselevel analysis of the main policy and structural determinants. Working Paper No. 68, European Bank for Reconstruction and Development, London.

http://ideas.repec.org/p/ebd/wpaper/68.html 


\section{Conomics}

The Open-Access, Open-Assessment E-Journal

Please note:

You are most sincerely encouraged to participate in the open assessment of this article. You can do so by either recommending the article or by posting your comments.

Please go to:

http://dx.doi.org/10.5018/economics-ejournal.ja.2012-19

The Editor 